\title{
Article \\ Seconeolitsine, the Novel Inhibitor of DNA Topoisomerase I, Protects against Invasive Pneumococcal Disease Caused by Fluoroquinolone-Resistant Strains
}

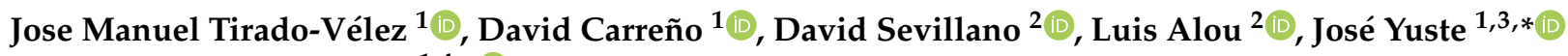 \\ and Adela G. de la Campa 1,4,*iD \\ 1 Centro Nacional de Microbiología, Instituto de Salud Carlos III, Majadahonda, 28220 Madrid, Spain; \\ jmtirvel@gmail.com (J.M.T.-V.); dcarreno@ic.ac.uk (D.C.) \\ 2 Microbiology Division-Department of Medicine, Universidad Complutense de Madrid, 28040 Madrid, Spain; \\ dsevill@med.ucm.es (D.S.); luisalou@med.ucm.es (L.A.) \\ 3 CIBER de Enfermedades Respiratorias, 28029 Madrid, Spain \\ 4 Presidencia, Consejo Superior de Investigaciones Científicas, 28006 Madrid, Spain \\ * Correspondence: jyuste@isciii.es (J.Y.); agcampa@isciii.es (A.G.d.1.C.); Tel.: +34-918-223-620 (J.Y.); \\ +34-918-223-944 (A.G.d.1.C.)
}

Citation: Tirado-Vélez, J.M.; Carreño, D.; Sevillano, D.; Alou, L.; Yuste, J.; de la Campa, A.G. Seconeolitsine, the Novel Inhibitor of DNA

Topoisomerase I, Protects against Invasive Pneumococcal Disease Caused by Fluoroquinolone-Resistant Strains. Antibiotics 2021, 10, 573. https://doi.org/10.3390/ antibiotics 10050573

Academic Editor:

Jesus Simal-Gandara

Received: 14 April 2021

Accepted: 9 May 2021

Published: 13 May 2021

Publisher's Note: MDPI stays neutral with regard to jurisdictional claims in published maps and institutional affiliations.

Copyright: (c) 2021 by the authors. Licensee MDPI, Basel, Switzerland. This article is an open access article distributed under the terms and conditions of the Creative Commons Attribution (CC BY) license (https:/ / creativecommons.org/licenses/by/ $4.0 /)$.

\begin{abstract}
Antibiotic resistance in Streptococcus pneumoniae has increased worldwide, making fluoroquinolones an alternative therapeutic option. Fluoroquinolones inhibit the type II DNA topoisomerases (topoisomerase IV and gyrase). In this study we have evaluated the in vivo activity of seconeolitsine, an inhibitor of topoisomerase I. Levofloxacin ( 12.5 to $50 \mathrm{mg} / \mathrm{kg}$ ) or seconeolitsine (5 to $40 \mathrm{mg} / \mathrm{kg}$ ) were administered every $12 \mathrm{~h}$ during two days in mice infected with a serotype 8-resistant strain. At $48 \mathrm{~h}$, a $70 \%$ protection was obtained with seconeolitsine $(40 \mathrm{mg} / \mathrm{kg} ; p<0.001)$. However, survival with levofloxacin was $20 \%$, regardless of the dose. In addition, seconeolitsine decreased bacteremia efficiently. Levofloxacin had higher levels in serum than seconeolitsine (Cmax of 14.7 vs. 1.6; $p<0.01)$ and higher values of area under the serum concentration-time curve ( $\mathrm{AUC}_{0-12 \mathrm{~h}}$ of 17.3 vs. 5 ; $p<0.01)$. However, seconeolitsine showed higher levels of time to peak concentration and elimination half-life. This is consistent with the higher binding of seconeolitsine to plasma proteins $(40 \%$ and $80 \%$ when used at $1 \mu \mathrm{g} / \mathrm{mL}$ and $50 \mu \mathrm{g} / \mathrm{mL}$, respectively) in comparison to levofloxacin $(12 \%$ at $5 \mu \mathrm{g} / \mathrm{mL}$ and $33 \%$ at $50 \mu \mathrm{g} / \mathrm{mL}$ ). Our results suggest that seconeolitsine would be a promising therapeutic alternative against pneumococcal isolates with high fluoroquinolone resistance levels.
\end{abstract}

Keywords: Streptococcus pneumoniae; DNA topoisomerase I inhibitor; seconeolitsine; resistance; invasive pneumococcal disease.

\section{Introduction}

Streptococcus pneumoniae (the pneumococcus) is an important cause of morbidity and mortality worldwide, and it is a major etiological agent of community-acquired pneumonia, meningitis, and acute otitis. It is the leading cause of severe pneumonia across the developing world, causing one million deaths annually among children aged $<5$ years [1-3]. In spite of the development of pneumococcal conjugate vaccines and antimicrobial chemotherapy, the pneumococcus continues to be one of the major human pathogens, due in part to its high rate of resistance to some antibiotics and in part to the low coverage and partial inefficiency of available vaccines [1,2]. The large number of pneumococcal serotypes has made prevention of the disease through vaccination challenging, since vaccine introductions have been followed by changes in serotype prevalence. After the introduction of the pneumococcal conjugate vaccines, the incidence of invasive pneumococcal disease (IPD) declined drastically, coinciding with a decrease in penicillin resistance [4-6]. However, emergence of serotypes not included in the vaccines and associated with antibiotic resistance is of great concern worldwide [7-9]. 
When antibiotic treatment is considered, resistance to currently used drugs for the treatment of pneumococcal infections, including beta-lactams and macrolides, has spread worldwide [10]. DNA supercoiling is an appropriate antimicrobial target, given that it is involved in DNA replication, transcription, and recombination [11]. An adequate level of DNA supercoiling is maintained by the DNA topoisomerase enzymes. S. pneumoniae possess three of these enzymes: two of type II (gyrase and topoisomerase IV), and a single type I enzyme, topoisomerase I (Topo I). The respiratory fluoroquinolones (FQs), such as levofloxacin (LVX) and moxifloxacin (MXF), which target the type II topoisomerases, are used for the treatment of adult patients with community-acquired pneumonia [12]. Fluoroquinolone resistance in S. pneumoniae is maintained at low level $(<3 \%)$ in Europe $[13,14]$, although higher rates have been detected in Asia [15], as well as in Canada [16]. However, an increase in resistance in this bacterium would occur if FQ use were increased [17].

Identification of compounds specifically targeting the type I topoisomerase family is scarce. Cheng et al. [18] have described one phenanthrene alkaloid able to inhibit the relaxation activity of Escherichia coli Topo I. However, no significant inhibition in cell growth was observed. We have described novel alkaloid compounds (seconeolitsine and N-methyl-seconeolitsine) that inhibited S. pneumoniae Topo I activity in vitro at concentrations equivalent to those inhibiting cell growth $(\sim 10 \mu \mathrm{M})$. These drugs inhibited the growth of multidrug-resistant (including FQ-resistant) clinical isolates [19] without affecting human cell viability and are envisaged as new therapeutic candidates for the treatment of pneumococcal infections resistant to other antibiotics. Seconeolitsine (SCN), a phenantrene alkaloid that is semi-synthesized from boldine [19] inhibits both Topo I activity and growth of S. pneumoniae $[19,20]$ and Mycobacterium tuberculosis [21]. In addition, SCN triggers a coordinated global transcriptional response in $S$. pneumoniae because of the increase of negative DNA supercoiling caused by inhibition of Topo I [20]. However, a definite proof of the in vivo activity of these drugs is still missing. In addition, the antimicrobial activity of these compounds has been recently demonstrated against multi-drug resistant isolates of M. tuberculosis and for the treatment of pneumococcal biofilms, confirming the therapeutic potential of these drugs against respiratory pathogens [21,22].

In this study, we investigated the efficacy of SCN in a mouse model of invasive disease in comparison with LVX.

\section{Materials and Methods}

\subsection{Bacterial Isolates, Growth, Typing, and Susceptibility Tests}

Isolates were serotyped by the Quellung reaction, a dot blot assay, and and/or by capsular sequence typing $[23,24]$. Genotyping was performed by pulse-field gel electrophoresis and multilocus sequence typing $[25,26]$. Five FQ-resistant isolates with characterized mutations were selected from a previous study [27]. Briefly, oligonucleotides parE398 and parC152 were used to amplify parE and parC QRDRs [27]. All isolates yielded fragments of $1.6 \mathrm{~kb}$. These PCR fragments were sequenced as described [27]. Oligonucleotides gyrA44 and gyrA170 were used to amplify and sequence gyrA QRDRs [27].

Bacteria were grown in Todd-Hewitt broth supplemented with $0.5 \%$ yeast extract (Difco) to an optical density at $580 \mathrm{~nm}$ (OD580) of 0.4 to 0.5 corresponding to ca. $10^{8} \mathrm{CFU} / \mathrm{mL}$. Single-use aliquots were stored at $-80{ }^{\circ} \mathrm{C}$ in $10 \%$ glycerol to use in mice infections as previously described [28-32]. Antimicrobial susceptibility was tested by broth microdilution, according to the Clinical and Laboratory Standards Institute guidelines. S. pneumoniae R6 was included as a quality control. Powders of known potency of LVX and MXF were purchased from Sigma. SCN was synthesized as previously described [19]. Briefly, for MIC determination, pneumococcal strains were grown in a casein hydrolysate-based medium with $0.3 \%$ sucrose as an energy source (AGCH medium). A 96-well plate was used including broth containing different concentrations of antibiotics. Plates were inoculated with a standardized suspension of the pneumococcal strains followed by incubation at $37{ }^{\circ} \mathrm{C}$ with $5 \% \mathrm{CO}_{2}$ for $18-24 \mathrm{~h}$. The minimal inhibitory concentrations (MICs) were deter- 
mined by observing the lowest concentration of the agent that inhibited visible growth of the bacterium.

\subsection{Animal Model Experiments}

BALB / c female mice (8-12 weeks old) weighing $20 \mathrm{~g}$ were purchased from Harlan Laboratories (Barcelona, Spain). These mice have been shown to be a good animal model to explore the protective activity of several antibiotics, including FQs [28,31,32]. The lethal dose of bacteria producing a $100 \%$ mortality rate $\left(\mathrm{LD}_{100}\right)$ over a period of 7 days was investigated by inoculating different concentrations of bacteria diluted in phosphatebuffered saline (PBS) $\mathrm{pH} 7.3$, by the intraperitoneal route as previously described $[28,31,33]$. To evaluate the protection level of SCN and LVX, animals were challenged with the $\mathrm{LD}_{100}$ $1 \mathrm{~h}$ before antibiotic treatment [28,31,33-35]. Different concentrations of antibiotic $(10,20$, and $40 \mathrm{mg} / \mathrm{kg}$ for SCN; 12.5, 25, and $50 \mathrm{mg} / \mathrm{kg}$ for LVX) were administered two times a day over $48 \mathrm{~h}$ by the subcutaneous route. The doses, interval, and schedule chosen were based in previous studies investigating the protective activity of FQs against pneumococcal sepsis in mice $[34,36,37]$. Seconeolitsine stock solution was dissolved in dimethyl sulfoxide (DMSO) and the doses tested for protection in animals were prepared in PBS containing 1\% DMSO. Animals in the lethal control groups were infected with S. pneumoniae and received the antibiotic solvent (PBS-1\% DMSO) instead of SCN or LVX. The toxicity control for each antibiotic (no infection group) only received SCN or LVX. Animal experiments were performed in groups of at least 5 mice and were repeated twice.

\subsection{Determination of Bacteria in Blood}

Bacteremic profiles (colony counts in blood) were determined from mice treated with SCN and LVX, at $24 \mathrm{~h}$ and $48 \mathrm{~h}$ post-infection, when the majority of mice were alive. To collect blood samples, volumes of $6 \mu \mathrm{l}$ were obtained from the tail vein, as previously described [28-31,33,38], resuspended in PBS and plated onto blood agar plates at $37^{\circ} \mathrm{C}$ in $5 \% \mathrm{CO}_{2}$ for colony counts determination.

\subsection{Determination Antibiotic Concentrations in Serum}

Groups of two mice for each antibiotic and time-point were treated with a single subcutaneous dose of $40 \mathrm{mg} / \mathrm{kg}$ of SCN or $50 \mathrm{mg} / \mathrm{kg}$ of LVX. Blood samples were collected at 15 and $30 \mathrm{~min}$ and 1, 2, 4, 6, 8, 10,12,14, 18, and $24 \mathrm{~h}$, centrifuged for 10 minutes at $2000 \mathrm{rpm}$, and the sera from the different mice were stored at $-80^{\circ} \mathrm{C}$ until drug assay determination.

Seconeolitsine concentrations were measured by high-pressure liquid chromatography analysis (HPLC). Chromatographic separation was performed using SunFire C18 column $(150 \times 4.6 \mathrm{~mm}$; Waters Corporation, MA, USA) with trifluoroacetic acid and acetonitrile in the ratio $70: 30(\mathrm{vol} . / \mathrm{vol}$.) as the mobile phase. The solvent flow rate was $1.0 \mathrm{~mL} / \mathrm{min}$ with a runtime of 20 minutes. The mobile phase was filtered through $0.45 \mu \mathrm{m}$ prior to use. Standards ranging from $0-1.000 \mu \mathrm{g} / \mathrm{mL}$ were prepared in HPLC grade methanol. Sample dilutions, prepared in mouse serum, were injected into the column at a constant volume of $20 \mu \mathrm{l}$ and were tested in duplicate. The detection wavelength was 270 by UV absorbance using a Waters UV-Visible 2489 module (Waters Corporation). The column was maintained at room temperature.

Levofloxacin concentrations were determined by bioassay using E. coli NCTC 10418 as indicator organism, as previously described [39]. Plates containing a lawn of microorganism were incubated for $18-24 \mathrm{~h}$ at $37^{\circ} \mathrm{C}$. Standards and dilutions were prepared in mouse serum in a range from $0.03-8 \mu \mathrm{g} / \mathrm{mL}$.

\subsection{Protein Binding}

Binding to serum proteins was determined by the ultrafiltration method (36) using the Centrifree micropartition system (Amicon Bioseparations, Millipore, Tullagreen, Ireland) with concentrations in murine plasma of 1 and $50 \mu \mathrm{g} / \mathrm{mL}$ for SCN and 5 and $50 \mu \mathrm{g} / \mathrm{mL}$ for LVX. Pre-filtered samples and ultrafiltrates recovered were measured by HPLC or bioassay, 
as described above. Percentage of SCN or LVX bound to proteins in mouse serum was calculated using the expression: [antibiotic in pre-filtered samples] - [antibiotic in ultrafiltrated samples]/[antibiotic in pre-filtered samples] $\times 100$ as previously described [40].

\subsection{Drug Pharmacokinetics and Pharmacokinetic/Pharmacodynamics (PK/PD) Parameters}

Pharmacokinetic $(\mathrm{PK})$ parameters measured included peak level $\left(\mathrm{C}_{\max }\right)$, time peak level $\left(\mathrm{T}_{\max }\right)$, area under the concentration time-curve from 0 to last $\left(\mathrm{C}_{\text {last }}\right)$ measured concentration $\left(A U C_{\text {last }}\right)$, and elimination half-life $\left(t_{1 / 2}\right)$. These parameters were estimated for both the total concentrations and the free fraction concentrations and were determined by using protein binding values, by a non-compartmental approach with the Phoenix WinNonlin program (version 6.2, Certara, NJ, USA). Pharmacodynamic (PD) index values (AUC/MIC ratio and T>MIC) were calculated over a period of $24 \mathrm{~h}$. T>MIC for total and unbound concentrations $(f \mathrm{~T}>\mathrm{MIC}$ ) were determined by a non-compartmental approach for PD data (Phoenix WinNonlin, model 220). AUC/MIC and $f$ AUC/MIC were calculated as twice the $\mathrm{AUC}_{0 \text {-last }}$ (or $f \mathrm{AUC}_{0 \text {-last }}$ ), since $\mathrm{C}_{\text {last }}$ was detected at times less than $12 \mathrm{~h}$.

\subsection{Statistical Analysis}

Statistical analysis was performed by using two-tailed Student's $t$-test (for two groups), whereas analysis of variance (ANOVA) was chosen for multiple comparisons. Survival was analyzed by the log-rank test. GraphPad InStat version 5.0 (GraphPad Software, CA, USA) was used for statistical analysis. Differences were considered statistically significant with $p<0.05\left({ }^{*}\right)$, highly significant with $p<0.01\left(^{* *}\right)$ and extremely significant with $\left.p<0.001{ }^{* * *}\right)$.

\subsection{Ethics Statement}

Animal experiments were performed at ISCIII in accordance with Spanish legislation (RD 1201/2005, RD 53/2013) and EU regulations (218/63/EU). All animal experiments were approved by the Animal Care and Use Committee of ISCIII (CBA PA 52_2011-v2 and PROEX 218/15).

\section{Results}

\subsection{Virulence among FQ-Resistant Clinical Isolates Varies within Serotype}

To investigate the LD100, we selected five FQ-resistant clinical isolates of four different serotypes from among those detected in a previous study, including Spanish isolates from year 2006 [27]. These strains were resistant to all FQs tested and also had resistance associated with other antibiotics (Table 1). All isolates were of serotypes $(8,15 \mathrm{~A}, 16 \mathrm{~F}$, and $33 \mathrm{~F})$ not included neither in the 10-valent or 13-valent pneumococcal conjugate vaccines. Three of them (CipR45, CipR57, and CipR72) belong to the Sweden15A-ST63 genotype, a major genotype among FQ-resistant isolates of the post-PCV7 vaccine isolates. In terms of virulence, isolates CipR45 and CipR57 of serotype 8 were able to produce $100 \%$ mortality within the first 48 hours, with LD100 of about $101 \mathrm{CFU} /$ mouse (Table 1), whereas strains of the other three serotypes were not virulent at the highest dose evaluated of $5 \times 10^{6} \mathrm{CFU} /$ mouse (Table 1). Based on these results, isolates CipR45 (low-level FQ-resistant, carrying a ParC with a S79F change) and CipR57 (high-level FQ-resistant, carrying ParCS79F and GyrAS81F changes) were selected for further experiments. The MICs of SCN for these strains were similar $(5.2 \mu \mathrm{g} / \mathrm{mL}$ for CipR45 and $2.6 \mu \mathrm{g} / \mathrm{mL}$ for CipR57; Table 1).

\subsection{In Vivo Efficacy Studies}

Protection mediated by LVX was tested in a low-level resistant isolate (CipR45, LVX MIC of $2 \mu \mathrm{g} / \mathrm{mL}$ ) and in a high-level resistant isolate (CipR57, LVX MIC of $16 \mu \mathrm{g} / \mathrm{mL}$ ). Treatment with LVX concentrations ranging from 12.5 to $50 \mathrm{mg} / \mathrm{kg}$ produced a delay in the death course of the mice in a dose-dependent manner when the infection was caused by the CipR45 isolate (Figure 1A). At $36 \mathrm{~h}$ post-infection, a survival of $100 \%, 80 \%$, and $40 \%$ was observed in the groups treated with LVX concentrations of $50 \mathrm{mg} / \mathrm{kg}, 25 \mathrm{mg} / \mathrm{kg}$ and $12.5 \mathrm{mg} / \mathrm{kg}$, respectively. At $78 \mathrm{~h}$ post-treatment all mice succumbed to the infection 
(Figure 1A). However, when the high-level resistant CipR57 was used, almost no delay in the death dynamics was observed at any of the concentrations investigated and all the animals died within the first $48 \mathrm{~h}$ post-infection, regardless of LVX exposure (Figure 1B).

Table 1. Phenotypic and genotypic properties of the isolates used in this study.

\begin{tabular}{|c|c|c|c|c|c|c|c|c|c|c|}
\hline \multirow{2}{*}{ Isolate } & \multirow{2}{*}{ Type $^{a}$} & \multicolumn{4}{|c|}{$\operatorname{MIC}(\mu \mathrm{g} / \mathrm{mL})^{b}:$} & \multirow{2}{*}{ Pattern $^{c}$} & \multicolumn{3}{|c|}{ QRDR Statuses ${ }^{\mathrm{d}}$ : } & \multirow{2}{*}{ MLD $^{\mathrm{e}}$} \\
\hline & & SCN & CIP & LVX & MXF & & ParC & ParE & GyrA & \\
\hline CipR5 & $33 \mathrm{~F}$ & 5.2 & 16 & 8 & 2.00 & EClCip & $\mathrm{D} 83 \mathrm{~N}$ & None & E85K & Avirulent \\
\hline CipR15 & $16 \mathrm{~F}$ & 2.6 & 32 & 16 & 4.00 & SxTCip & S79F & None & S81F & Avirulent \\
\hline CipR45 & 8 & 5.2 & 4 & 2 & 0.25 & TEClCip & S79F & None & None & $\geq 5 \times 10^{1}$ \\
\hline CipR57 & 8 & 2.6 & 64 & 16 & 4.00 & TECip & S79F & None & S81F & $\geq 5 \times 10^{1}$ \\
\hline CipR72 & $15 \mathrm{~A}$ & 5.2 & 64 & 32 & 4.00 & PTEClCip & S79F & E474K & $\mathrm{S} 81 \mathrm{~F}$ & Avirulent \\
\hline
\end{tabular}

${ }^{a}$ Serotype; ${ }^{b}$ SCN, seconeolitsine; CIP, ciprofloxacin; LVX, levofloxacin; MXF, moxifloxacin; ${ }^{c}$ Pattern of resistance: $\mathrm{P}$, resistant to penicillin (MICs of 0.12 to $4 \mu \mathrm{g} / \mathrm{mL}$ ); T, resistant to tetracycline (MICs $\geq 4 \mu \mathrm{g} / \mathrm{mL}$ ); C, resistant to chloramphenicol (MICs $\geq 8 \mu \mathrm{g} / \mathrm{mL}$ ); E, resistant to erythromycin (MICs $\geq 0.5 \mu \mathrm{g} / \mathrm{mL}$ ); Cip: resistant to ciprofloxacin (MICs $\geq 4 \mu \mathrm{g} / \mathrm{mL}$ ). ${ }^{\mathrm{d}} \mathrm{QRDR}$, Quinolone-resistance determining regions. Only amino acid changes involved in fluoroquinolone resistance are indicated. ${ }^{\mathrm{e}}$ MLD, minimal lethal dose that produced a $100 \%$ mortality rate at day 2 .

To explore the putative protection of new compound SCN, the efficacy of this drug was tested in mice treated with 5,10,20, and $40 \mathrm{mg} / \mathrm{kg}$ of SCN after infection with the high-level resistant CipR57 strain. At $36 \mathrm{~h}$ post-infection, survival values of $70 \%(40 \mathrm{mg} / \mathrm{kg})$, and $60 \%$ ( $20 \mathrm{mg} / \mathrm{kg}$ to $5 \mathrm{mg} / \mathrm{kg}$ ) were observed (Figure 1C). After 7 days, survival rate among the different groups treated with SCN was still between $40 \%$ and $50 \%$. These results indicate that SCN not only was able to induce a significant delay in terms of mortality but was even able to allow the long-term survival of half the animals against pneumococcal sepsis.

Seconeolitsine caused a decrease of bacterial counts in blood. Bacterial loads at 24 and $48 \mathrm{~h}$ post-infection were determined for the experiment in which the high-level LVX resistant CipR57 strain was used. Treatment with doses of $25 \mathrm{mg} / \mathrm{kg}$ and $50 \mathrm{mg} / \mathrm{kg}$ of Levofloxacin did not reduce bacterial levels in blood compared to the untreated group at any of the time-points investigated (Figure 2). However, treatment with different doses of SCN significantly reduced bacterial load (Figure 2). In this sense, whereas untreated animals or mice treated with LVX had around $10^{8} \mathrm{CFU} / \mathrm{mL}$ bacterial levels in blood at $24 \mathrm{~h}$, mice treated with SCN carried lower quantities of bacteria, with levels around $10^{4}-10^{5} \mathrm{CFU} / \mathrm{mL}$ (Figure 2A). This effect was even more dramatic at $48 \mathrm{~h}$ post-infection, indicating that SCN has an important effect in preventing bacterial replication within the blood (Figure 2B). High levels of bacterial counts were found in blood of mice treated with LVX, whereas a significant proportion of mice treated with $\mathrm{SCN}$ were free of bacteria within the first $48 \mathrm{~h}$, demonstrating that SCN showed bactericidal activity in vivo (Figure 2). Overall, our results confirm that $\mathrm{SCN}$ can induce bacterial clearance from the systemic circulation against sepsis caused by pneumococcal strains harboring high levels of resistance to FQs. 
A

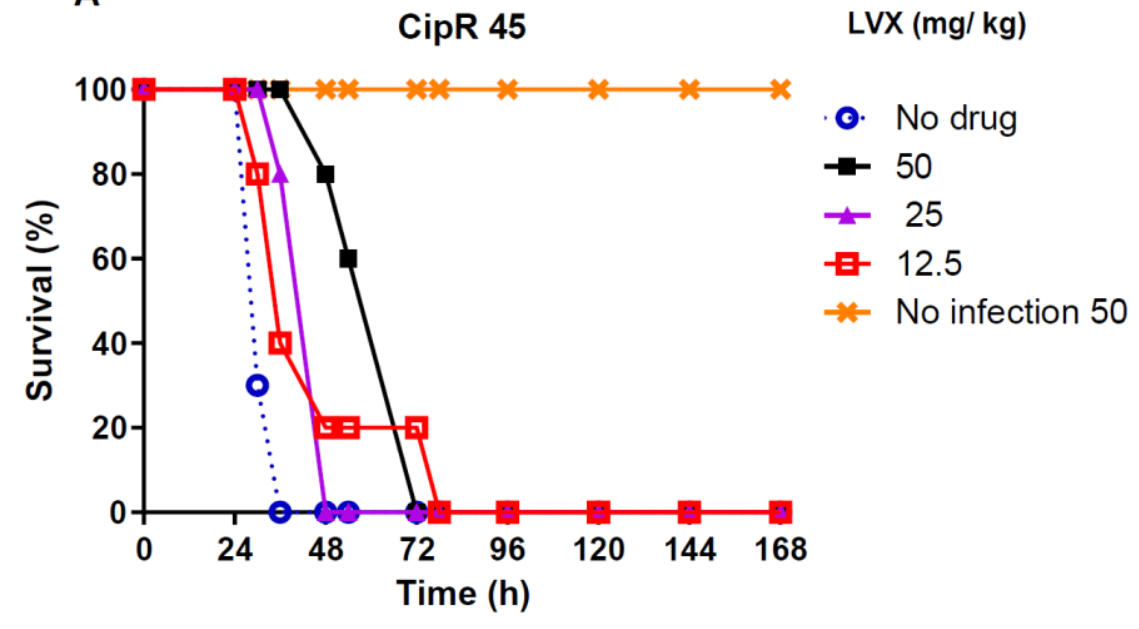

B

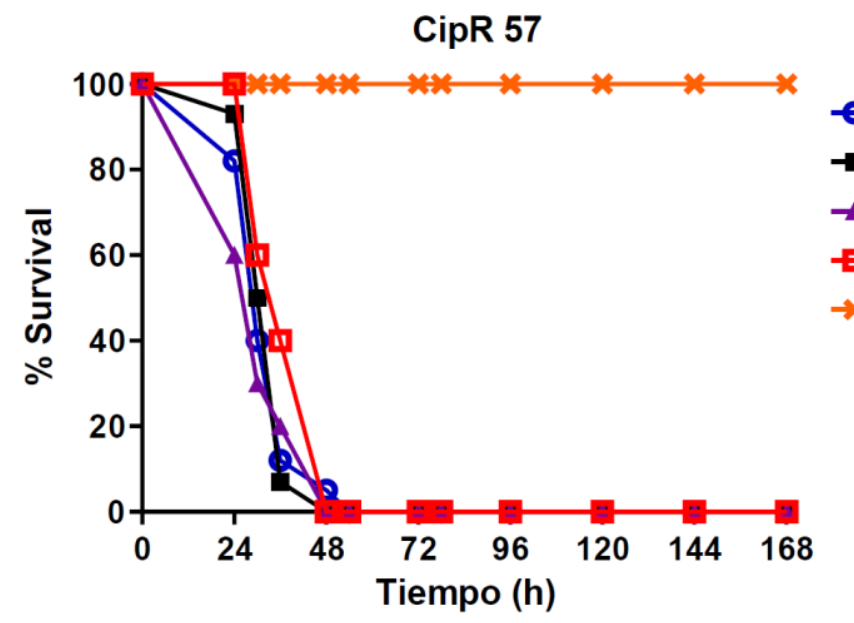

$\operatorname{LVX}(\mathrm{mg} / \mathrm{kg})$

No drug

$\rightarrow 50$

$+25$

母 12,5

* No infection 50

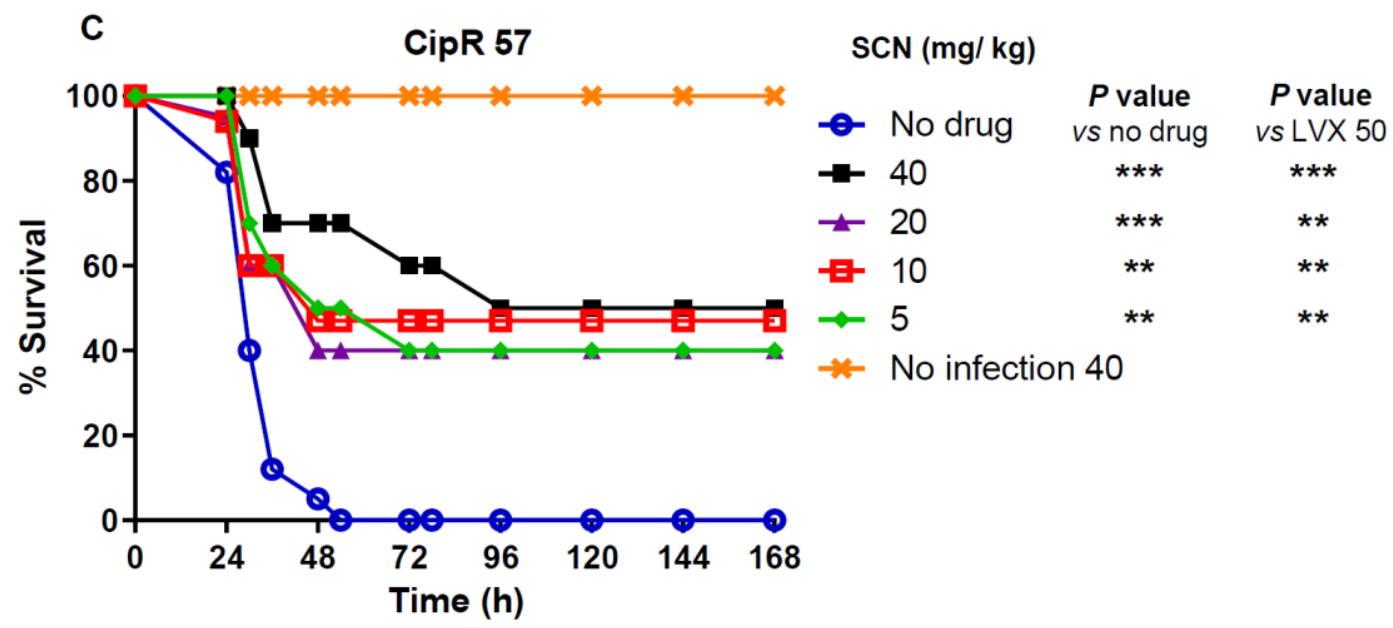

Figure 1. Percentage survival of groups of 5 mice intraperitonealy infected with two times the MLD $\left(1 \times 10^{2} \mathrm{CFU} / \mathrm{mouse}\right)$ of isolate CipR45 (A) or CipR57 (B,C). Experiments were followed over a 7-day period. Antibiotic treatment or placebo was administered subcutaneously every $12 \mathrm{~h}$ during the first $48 \mathrm{~h}$. The doses of each antibiotic administered are indicated for LVX (A and B) or SCN (C). Data are the average of 2 (for SCN $40 \mathrm{mg} / \mathrm{kg}$ ) to 4 independent replicates. The long rank test was used for survival curve comparison between the no drug group and the groups treated with the indicated SCN concentrations. $p$ values are: ${ }^{* *} p<0.01 ;{ }^{* *} p<0.001$. 


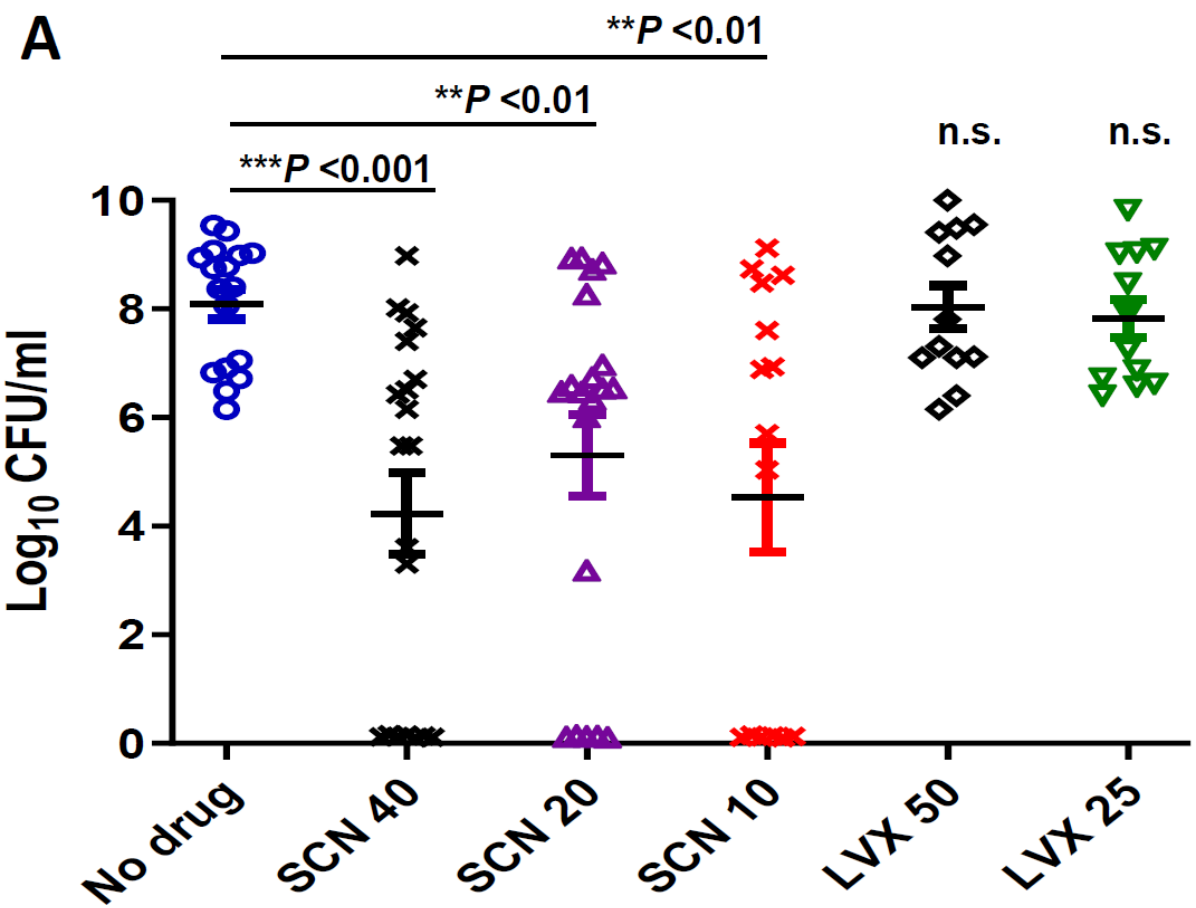

B ${ }^{*} P<0.05$

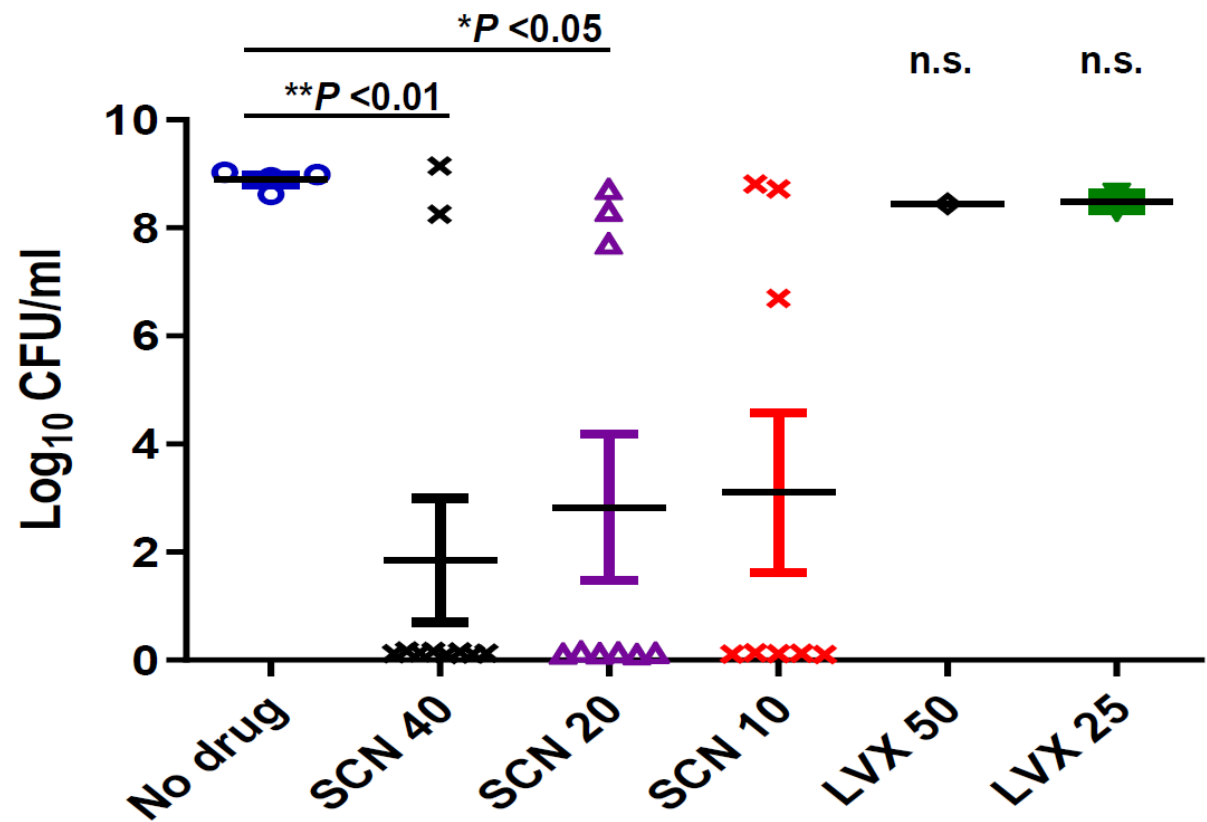

Figure 2. Determination of bacterial counts in the blood of at least 10 mice. To measure the level of bacteria in the bloodstream, blood samples were collected from the tail of the mice of each group at (A) $24 \mathrm{~h}$ or (B) $48 \mathrm{~h}$ after infection, plated on blood agar and incubated at $37^{\circ} \mathrm{C}$ in $5 \% \mathrm{CO}_{2}$ for $24 \mathrm{~h}$. Data are the average of 3 independent replicates. The $t$-test was used to estimate the difference between the treated groups and the untreated (no drug) group. The symbols for $p$ values are: ${ }^{*} p<0.05 ;{ }^{* *} p<0.01,{ }^{* * *} p<0.001$ and n.s.: not significant. For multiple comparisons of the different doses of SCN (one-way ANOVA with a post hoc Dunnett test); $p<0.01$ and $p<0.05$ for $24 \mathrm{~h} \mathrm{(A)} \mathrm{and} \mathrm{48h} \mathrm{(B)} \mathrm{respectively.} \mathrm{The} \mathrm{comparison}$ of different doses of SCN with LVX was statistically significant at $24 \mathrm{~h}$ when the majority of mice were alive $(p<0.01$ for SCN 40 vs. LVX 50 and 25; $p<0.05$ for SCN 20 vs. LVX 50 and 25 and $p<0.01$ for SCN 10 vs. LVX 50 and 25). 


\subsection{Pharmacokinetic and PK/PD Parameters}

Different flow rates, solvent systems, and ratios for the mobile phase were studied in order to obtain a sharp SCN peak with a shorter retention time. The solvent system comprising trifluoroacetic acid and acetonitrile $70: 30 \mathrm{vol} . / \mathrm{vol}$. at a flow rate of $1 \mathrm{~mL} / \mathrm{min}$ gave optimal separation at a retention time of approximately 7 to $8 \mathrm{~min}$. The assay was linear over the range $0-200 \mu \mathrm{g} / \mathrm{mL}(\mathrm{r} 2=0.9987)$, with a lower detection limit of $0.25 \mu \mathrm{g} / \mathrm{mL}$. Interday coefficient of variation (CV) was $4.5 \%$. The bioassay for LVX was linear over the range tested $(\mathrm{r} 2=0.995)$ with a lower limit of detection of $0.03 \mu \mathrm{g} / \mathrm{mL}$. Interday and intraday CVs were lower than $5.2 \%$.

The mean serum concentration-time profiles of single subcutaneous doses of $40 \mathrm{mg} / \mathrm{kg}$ of SCN or $50 \mathrm{mg} / \mathrm{kg}$ of LVX (the highest doses used in efficacy studies) in non-infected mice are shown in Figure 3.
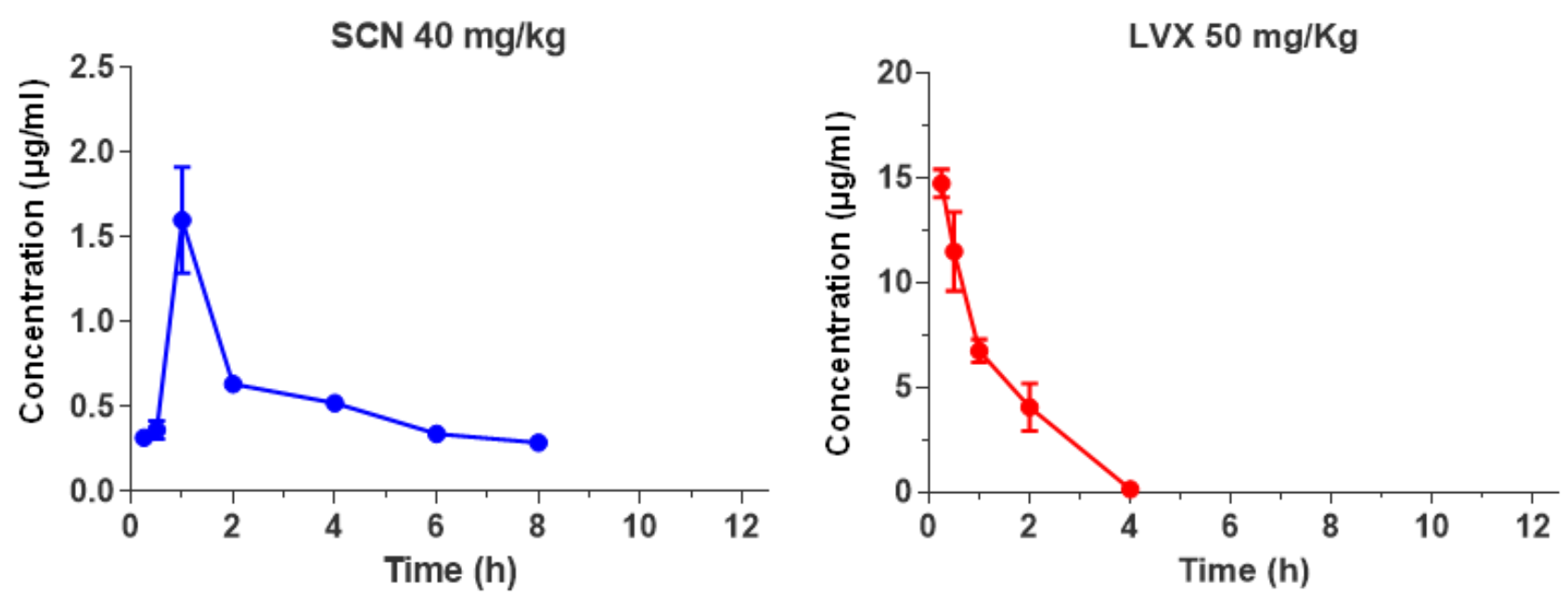

Figure 3. Serum drug concentrations $(\mu \mathrm{g} / \mathrm{mL})$ of SCN and LVX after single dose administration of $40 \mathrm{mg} / \mathrm{kg}$ or $50 \mathrm{mg} / \mathrm{kg}$, respectively.

Pharmacokinetic and PK/PD parameters estimated for both antibiotics are listed in Table 2. The half-life of SCN was prolonged, $7.8 \mathrm{~h}$, in comparison with the half-life of LVX, $0.7 \mathrm{~h}$, but the peak dose values for SCN were significantly lower than those observed for LVX (1.6 vs. $14.7 \mu \mathrm{g} / \mathrm{mL}$, respectively). The protein binding level was concentration dependent for both antimicrobials, ranging from $40 \%$ to $80 \%$ for SCN at concentrations of 1 and $50 \mu \mathrm{g} / \mathrm{mL}$, and from $12 \%$ to $33 \%$ for LVX at concentrations of 5 and $50 \mu \mathrm{g} / \mathrm{mL}$, respectively. A protein binding value of $40 \%$ for SCN and $12 \%$ for LVX was chosen for determination of $\mathrm{PK} / \mathrm{PD}$ parameters for free drug, since these percentages were more closely related to drug levels achieved by SCN or LVX at the doses tested. As shown in Table 2, magnitudes of PK/PD parameters of SCN exposed in our murine model against CipR45 and CipR57 were very low ( $f$ AUC $/ \mathrm{MIC} \leq 1.9 \mathrm{~h}$ and $f \mathrm{~T}>\mathrm{MIC}=0)$. This is consistent with the free serum SCN levels maintained below the MIC achieved during the entire dosage interval for both CipR isolates. In contrast, LVX $f$ AUC/MIC ratios derived from the dose tested were very low $(\leq 15.2 \mathrm{~h})$ even when the low-level FQ-resistant isolate was considered (Table 2). 
Table 2. Pharmacokinetic (mean \pm standard deviation) and PK/PD parameters of seconeolitsine and levofloxacin measured in pooled sera obtained after subcutaneous inoculation of a single dose of $40 \mathrm{mg} / \mathrm{kg}$ or $50 \mathrm{mg} / \mathrm{kg}$ respectively.

\begin{tabular}{|c|c|c|c|}
\hline PK Parameters & Seconeolitsine & Levofloxacin & $p$ Values \\
\hline $\mathrm{C}_{\max }(\mu \mathrm{g} / \mathrm{mL})$ & $1.6 \pm 0.3$ & $14.7 \pm 0.7$ & $<0.01$ \\
\hline $\mathrm{C}_{\min }(\mu \mathrm{g} / \mathrm{mL})$ & $0.3 \pm 0.04$ & $0.1 \pm 0.0$ & $<0.05$ \\
\hline $\mathrm{T}_{\max }(\mathrm{h})$ & $1.0 \pm 0.0$ & $0.25 \pm 0.0$ & $<0.001$ \\
\hline$t_{1 / 2}(h)$ & $7.8 \pm 2.4$ & $0.7 \pm 0.0$ & 0.054 \\
\hline $\mathrm{T}_{\text {last }}(\mathrm{h})$ & $9.0 \pm 1.4$ & $4.0 \pm 0.0$ & $<0.5$ \\
\hline $\mathrm{AUC}_{0-12 \mathrm{~h}}(\mu \mathrm{g} / \mathrm{mL} \times \mathrm{h})$ & $5.0 \pm 0.0$ & $17.3 \pm 1.5$ & $<0.01$ \\
\hline $\mathrm{AUC}_{0-24 \mathrm{~h}}(\mu \mathrm{g} / \mathrm{mL} \times \mathrm{h})$ & $10.0 \pm 0.1$ & $34.6 \pm 2.9$ & $<0.01$ \\
\hline \multicolumn{4}{|l|}{ PK/PD parameters } \\
\hline Strain CipR45; MIC ( $\mu \mathrm{g} / \mathrm{mL})$ & 5.2 & 2 & \\
\hline$f A U C / M I C(h)$ & $1.61 \pm 0.0$ & $15.2 \pm 1.3$ & $<0.01$ \\
\hline$f \mathrm{~T}>\mathrm{MIC}(\%)$ & 0.0 & $24.2 \pm 2.8$ & - \\
\hline Strain CipR57; MIC ( $\mu \mathrm{g} / \mathrm{mL})$ & 2.6 & 16 & \\
\hline$f A U C / M I C(h)$ & $2.3 \pm 0.0$ & $1.9 \pm 0.16$ & 0.074 \\
\hline$f \mathrm{~T}>\mathrm{MIC}(\%)$ & 0.0 & 0.0 & - \\
\hline
\end{tabular}

\section{Discussion}

To evaluate the in vivo activity of SCN, we tested several clinical isolates with wellcharacterized mechanisms of FQ resistance. The most virulent isolates were two isolates of serotype 8 belonging to the Sweden15A-ST63 genotype. Serotype 8, which is not included either in PCV7 or PCV-13 vaccines, has been responsible for some invasive outbreaks reported in Spain in recent years, both in healthy individuals [41] and HIV patients [42]. These isolates were originated by recombination of the loci encoding capsule 8 into the multi-drug resistant Sweden15A-ST63 clone [26]. The inclusion of clinical isolates of serotype 8 to test the antimicrobial effect of SCN is relevant from the epidemiological perspective, because serotype 8 is currently the most frequent cause of pneumococcal disease in the adult population and is rising in children [7-9,43,44].

We observed that treatment with LVX exerted some protection against infection by CipR45, in accordance with its low level of resistance to LVX. This is consistent with previous studies showing that different FQs induce certain degrees of protection against pneumococcal strains with resistance levels to LVX $\leq 2 \mu \mathrm{g} / \mathrm{mL}[34,36]$. However, the LVX exposures against the CipR45 isolate used in our animal model were insufficient for efficacy, as confirmed by the low rates of survival beyond $48 \mathrm{~h}$ of treatment. Data from non-neutropenic mice infected with S. pneumoniae estimated that LVX fAUC/MIC ratios greater than $25 \mathrm{~h}$ are associated with a $90 \%$ survival; i.e., efficacy when mortality is used as efficacy endpoint $[45,46]$. Higher $f$ AUC/MIC ratios $(>100 \mathrm{~h}$ ) would be required to prevent the emergence of LVX-resistant mutants in environments with first step bacterial mutants [47]. These magnitudes are substantially greater than the LVX exposures used in this study ( $f$ AUC/MIC $\leq 15.2 \mathrm{~h} ; p<0.01$ ), even when the highest LVX dose was tested. As expected, when isolate CipR57 containing a high level of resistance to LVX was used, no protection was observed. These results confirmed previous findings by other authors demonstrating poor efficacy of treatment with LVX against sepsis caused by S. pneumoniae strains with parC and gyrA mutations and also support the validity of the animal model used [34,36].

As an alternative antibiotic strategy to fight pneumococcal sepsis caused by clinical isolates with high levels of resistance to FQ, we used $\mathrm{SCN}$ as a novel drug targeting a new target, Topo I. In this sense, we have demonstrated that the antimicrobial activity of this compound was very high against different multidrug pneumococcal resistant strains including those with high levels of MIC to FQs [19]. In addition, SCN is effective against multidrug resistant strains of $M$. tuberculosis and reduces the adherence and thickness of pneumococcal biofilms [21,22]. In this study, SCN showed a high capacity of protection against $S$. pneumoniae infection, even at the lower dose tested, $5 \mathrm{mg} / \mathrm{kg}(p<0.01)$. After 
7 days, survival rate was still of $40 \%$ to $50 \%$, regardless of the dose of SCN administered $(p<0.01)$. This was contrary to what happened in LVX-treated mice, which all died within the first $48 \mathrm{~h}$. The survival was directly related to the ability of SCN to reduce the number of viable pneumococci present in the plasma of the mice, both at 24 and $48 \mathrm{~h}$ after infection. This number was significantly lower in those mice treated with $40 \mathrm{mg} / \mathrm{kg}$ of SCN compared with a control group $(p<0.001)$ and also with the mice group treated with LVX $(p<0.001)$. These results confirm previous studies by our group, demonstrating that SCN has antibacterial activity both in vitro and in vivo and might be a promising alternative against S. pneumoniae strains with high levels of resistance to FQs [19].

The pharmacokinetic study of SCN demonstrated a long half-life in mice and peak concentrations below the MIC of strains CipR45 and CipR57 after the administration of a $40 \mathrm{mg} / \mathrm{kg}$ single dose. From a pharmacodynamic perspective, these observations are of great interest, since very low SCN exposures ( $f$ AUC /MIC ratios $\leq 2.3 \mathrm{~h}$ ) were associated with high survival rates of mice after $48 \mathrm{~h}$ of treatment $(p<0.01)$.

In addition, SCN at the largest concentration used $(40 \mathrm{mg} / \mathrm{kg})$ was not harmful as all non-infected mice were alive and their aspect remained healthy after 7 days (Figure 1C). Breathing, hair, eyes, appetite, movement, and weight were all normal parameters during the 7 days of follow-up. This is consistent with the very low cytotoxic activity of different alkaloids targeting Topo I that exhibit efficient antitrypanosomal activity [48,49]. Hence, since $\mathrm{SCN}$ response increased in a dose-dependent manner, a higher dose could improve the effectiveness of SCN when tolerable. Although SCN-derived metabolites were not detected in murine plasma by HPLC, their presence cannot be discounted since the quantification of SCN could not be performed by microbiological methods, probably due to poor hydrosolubility of this molecule (data not shown). Thus, the pharmacological activity of SCN in this model cannot be attributed solely to the parent compound.

Overall, we have proved that SCN is effective in a mouse model of pneumococcal bacteremia. Dose-response studies using higher tolerable SCN doses are guaranteed to provide the magnitude of PK/PD parameters required for efficacy on pneumococcal isolates. Topo I has an essential role in supporting transcription in S. pneumoniae. We have shown that Topo I and RNA polymerase physically interact in vitro and colocalize at gene promoters in vivo. Binding of each of these enzymes to promoters was prevented by the specific inhibition of the other enzyme, either by rifampicin (RNA polymerase) or by SCN (Topo I), supporting a role for Topo I in RNA polymerase transcription [50]. These results allowed envisaging SCN as a new drug for the treatment of diseases caused by infection with multi-drug resistant strains of S. pneumoniae.

\section{Conclusions}

Antibiotic resistance and reducing its impact on public health is one of the top priorities worldwide in the fight against infectious diseases. Hence, we demonstrate that seconeolitsine, which is an inhibitor of Topo I, is effective against systemic infection of S. pneumoniae. Administration of this drug was able to control bacterial replication within the systemic circulation, leading to increased survival rates. This study has analyzed the antimicrobial activity of this compound against pneumococcal sepsis, suggesting the potential of seconeolitsine as a promising therapeutic agent against pneumococcal infection.

Author Contributions: Conceptualization, J.M.T.-V., D.C., J.Y. and A.G.d.l.C.; methodology, J.M.T.-V., D.C., D.S., L.A., and J.Y.; formal analysis, J.M.T.-V., D.C., D.S., L.A., J.Y., and A.G.d.l.C.; investigation, J.M.T.-V., D.C., D.S., L.A., and J.Y.; writing—original draft preparation, J.Y. and A.G.d.l.C.; writingreview and editing, J.M.T.-V., D.C., D.S., L.A., J.Y., and A.G.d.l.C. All authors have read and agreed to the published version of the manuscript.

Funding: This research was funded by Ministerio de Economía, Industria y Competitividad (grants BIO2017-82951-R to A.G.d.1.C. and SAF2017-83388 to J.Y.). CIBER de Enfermedades Respiratorias (CIBERES) is an initiative of ISCIII. 
Institutional Review Board Statement: The study was approved by Ethics Committee of the Animal Care and Use Committee of ISCIII (CBA PA 52_2011-v2 and PROEX 218/15) in accordance with Spanish legislation (RD 1201/2005, RD 53/2013) and EU regulations (218/63/EU).

Informed Consent Statement: Not applicable.

Data Availability Statement: The data presented in this study are contained within the article.

Acknowledgments: We thank Antonio J. Martín-Galiano for critical reading of the manuscript.

Conflicts of Interest: The authors declare no conflict of interest related to this work. The funders had no role in the design of the study; in the collection, analyses, or interpretation of data; in the writing of the manuscript, or in the decision to publish the results.

\section{References}

1. GBD 2016 Lower Respiratory Infections Collaborators. Estimates of the global, regional, and national morbidity, mortality, and aetiologies of lower respiratory infections in 195 countries, 1990-2016: A systematic analysis for the Global Burden of Disease Study 2016. Lancet Infect. Dis. 2018, 18, 1191-1210. [CrossRef]

2. Wahl, B.; O’Brien, K.L.; Greenbaum, A.; Majumder, A.; Liu, L.; Chu, Y.; Luksic, I.; Nair, H.; McAllister, D.A.; Campbell, H.; et al. Burden of Streptococcus pneumoniae and Haemophilus influenzae type b disease in children in the era of conjugate vaccines: Global, regional, and national estimates for 2000-15. Lancet Glob. Health 2018, 6, e744-e757. [CrossRef]

3. O’Brien, K.L.; Wolfson, L.J.; Watt, J.P.; Henkle, E.; Deloria-Knoll, M.; McCall, N.; Lee, E.; Mulholland, K.; Levine, O.S.; Cherian, T. Burden of disease caused by Streptococcus pneumoniae in children younger than 5 years: Global estimates. Lancet 2009, 374, 893-902. [CrossRef]

4. Pilishvili, T.; Lexau, C.; Farley, M.M.; Hadler, J.; Harrison, L.H.; Bennett, N.M.; Reingold, A.; Thomas, A.; Schaffner, W.; Craig, A.S.; et al. Sustained reductions in invasive pneumococcal disease in the era of conjugate vaccine. J. Infect. Dis. 2010, $201,32-41$. [CrossRef] [PubMed]

5. Fenoll, A.; Granizo, J.J.; Giménez, M.J.; Yuste, J.; Aguilar, L. Secular trends (1990-2013) in serotypes and associated nonsusceptibility of $S$. pneumoniae isolates causing invasive disease in the pre-/post-era of pneumococcal conjugate vaccines in Spanish regions without universal paediatric pneumococcal vaccination. Vaccine 2015, 33, 5691-5699. [CrossRef] [PubMed]

6. Moore, M.R.; Link-Gelles, R.; Schaffner, W.; Lynfield, R.; Lexau, C.; Bennett, N.M.; Petit, S.; Zansky, S.M.; Harrison, L.H.; Reingold, A.; et al. Effect of use of 13-valent pneumococcal conjugate vaccine in children on invasive pneumococcal disease in children and adults in the USA: Analysis of multisite, population-based surveillance. Lancet Infect. Dis. 2015, 15, 301-309. [CrossRef]

7. Ladhani, S.N.; Collins, S.; Djennad, A.; Sheppard, C.L.; Borrow, R.; Fry, N.K.; Andrews, N.J.; Miller, E.; Ramsay, M.E. Rapid increase in non-vaccine serotypes causing invasive pneumococcal disease in England and Wales, 2000-2017: A prospective national observational cohort study. Lancet Infect. Dis. 2018, 18, 441-451. [CrossRef]

8. de Miguel, S.; Domenech, M.; González-Camacho, F.; Sempere, J.; Vicioso, D.; Sanz, J.C.; García Comas, L.; Ardanuy, C.; Fenoll, A.; Yuste, J. Nationwide trends of invasive pneumococcal disease in Spain (2009-2019) in children and adults during the pneumococcal conjugate vaccine era. Clin. Infect. Dis. 2020. [CrossRef]

9. Ouldali, N.; Varon, E.; Levy, C.; Angoulvant, F.; Georges, S.; Ploy, M.C.; Kempf, M.; Cremniter, J.; Cohen, R.; Bruhl, D.L.; et al. Invasive pneumococcal disease incidence in children and adults in France during the pneumococcal conjugate vaccine era: An interrupted time-series analysis of data from a 17-year national prospective surveillance study. Lancet Infect. Dis. 2020, 121, 137-147. [CrossRef]

10. Jacobs, M.R.; Felmingham, D.; Appelbaum, P.C.; Gruneberg, R.N.; Alexander Project Group. The Alexander Project 1998-2000: Susceptibility of pathogens isolated from community-acquired respiratory tract infection to commonly used antimicrobial agents. J. Antimicrob. Chemother. 2003, 52, 229-246. [CrossRef]

11. Champoux, J.J. DNA topoisomerases: Structure, function, and mechanism. Annu. Rev. Biochem. 2001, 70, 369-413. [CrossRef]

12. Mandell, L.A.; Wunderink, R.G.; Anzueto, A.; Bartlett, J.G.; Campbell, G.D.; Dean, N.C.; Dowell, S.F.; File, T.M., Jr.; Musher, D.M.; Niederman, M.S.; et al. Infectious Diseases Society of America/American Thoracic Society consensus guidelines on the management of community-acquired pneumonia in adults. Clin. Infect. Dis. 2007, 44 (Suppl. 2), S27-S72. [CrossRef] [PubMed]

13. Riedel, S.; Beekmann, S.E.; Heilmann, K.P.; Richter, S.S.; García-de-Lomas, J.; Ferech, M.; Goosens, H.; Doern, G.V. Antimicrobial use in Europe and antimicrobial resistance in Streptococcus pneumoniae. Eur. J. Clin. Microbiol. Infect. Dis. 2007, 26, 485-490. [CrossRef]

14. Domenech, A.; Tirado-Vélez, J.M.; Fenoll, A.; Ardanuy, C.; Yuste, J.; Linares, J.; de la Campa, A.G. Fluoroquinolone-resistant pneumococci: Dynamics of serotypes and clones in Spain in 2012 compared with those from 2002 and 2006. Antimicrob. Agents Chemother. 2014, 58, 2393-2399. [CrossRef] [PubMed]

15. Fuller, J.D.; Low, D.E. A review of Streptococcus pneumoniae infection treatment failures associated with fluoroquinolone resistance. Clin. Infect. Dis. 2005, 41, 118-121. [CrossRef] [PubMed]

16. Adam, H.J.; Hoban, D.J.; Gin, A.S.; Zhanel, G.G. Association between fluoroquinolone usage and a dramatic rise in ciprofloxacinresistant Streptococcus pneumoniae in Canada, 1997-2006. Int. J. Antimicrob. Agents 2009, 34, 82-85. [CrossRef] 
17. Chen, D.K.; McGeer, A.; de Azavedo, J.C.; Low, D.E. Decreased susceptibility of Streptococcus pneumoniae to fluoroquinolones in Canada. Canadian Bacterial Surveillance Network. N. Engl. J. Med. 1999, 341, 233-239. [CrossRef]

18. Cheng, B.; Liu, I.F.; Tse-Dinh, Y.C. Compounds with antibacterial activity that enhance DNA cleavage by bacterial DNA topoisomerase I. J. Antimicrob. Chemother. 2007, 59, 640-645. [CrossRef]

19. García, M.T.; Blázquez, M.A.; Ferrándiz, M.J.; Sanz, M.J.; Silva-Martín, N.; Hermoso, J.A.; de la Campa, A.G. New alkaloid antibiotics that target the DNA topoisomerase I of Streptococcus pneumoniae. J. Biol. Chem. 2011, 286, 6402-6413. [CrossRef]

20. Ferrándiz, M.J.; Martín-Galiano, A.J.; Arnanz, C.; Camacho-Soguero, I.; Tirado-Vélez, J.M.; de la Campa, A.G. An increase in negative supercoiling in bacteria reveals topology-reacting gene clusters and a homeostatic response mediated by the DNA topoisomerase I gene. Nucleic Acids Res. 2016, 44, 7292-7303. [CrossRef]

21. García, M.T.; Carreno, D.; Tirado-Vélez, J.M.; Ferrándiz, M.J.; Rodrigues, L.; Gracia, B.; Amblar, M.; Ainsa, J.A.; de la Campa, A.G. Boldine-derived alkaloids inhibit the activity of DNA topoisomerase I and growth of Mycobacterium tuberculosis. Front. Microbiol. 2018, 9, 1659. [CrossRef]

22. Valenzuela, M.V.; Domenech, M.; Mateos-Martínez, P.; González-Camacho, F.; de la Campa, A.G.; García, M.T. Antibacterial activity of a DNA topoisomerase I inhibitor versus fluoroquinolones in Streptococcus pneumoniae. PLoS ONE 2020, 15, e0241780. [CrossRef] [PubMed]

23. Fenoll, A.; Jado, I.; Vicioso, D.; Casal, J. Dot blot assay for the serotyping of pneumococci. J. Clin. Microbiol. 1997, 35, 764-766. [CrossRef] [PubMed]

24. Elberse, K.E.; van de Pol, I.; Witteveen, S.; van der Heide, H.G.; Schot, C.S.; van Dijk, A.; van der Ende, A.; Schouls, L.M. Population structure of invasive Streptococcus pneumoniae in The Netherlands in the pre-vaccination era assessed by MLVA and capsular sequence typing. PLoS ONE 2011, 6, e20390. [CrossRef] [PubMed]

25. Enright, M.C.; Spratt, B.G. A multilocus sequence typing scheme for Streptococcus pneumoniae: Identification of clones associated with serious invasive disease. Microbiology 1998, 144, 3049-3060. [CrossRef] [PubMed]

26. Ardanuy, C.; de la Campa, A.G.; García, E.; Fenoll, A.; Calatayud, L.; Cercenado, E.; Pérez-Trallero, E.; Bouza, E.; Linares, J. Spread of Streptococcus pneumoniae serotype 8-ST63 multidrug-resistant recombinant Clone, Spain. Emerg. Infect. Dis. 2014, 20, 1848-1856. [CrossRef]

27. de la Campa, A.G.; Ardanuy, C.; Balsalobre, L.; Pérez-Trallero, E.; Marimón, J.M.; Fenoll, A.; Linares, J. Changes in fluoroquinoloneresistant Streptococcus pneumoniae after 7-valent conjugate vaccination, Spain. Emerg. Infect. Dis. 2009, 15, 905-911. [CrossRef]

28. Cafini, F.; Yuste, J.; Giménez, M.J.; Sevillano, D.; Aguilar, L.; Alou, L.; Ramos-Sevillano, E.; Torrico, M.; González, N.; García, E.; et al. Enhanced in vivo activity of cefditoren in pre-immunized mice against penicillin-resistant S. pneumoniae (serotypes 6B, 19F and 23F) in a sepsis model. PLoS ONE 2010, 5, e12041. [CrossRef]

29. Ramos-Sevillano, E.; Urzainqui, A.; de Andrés, B.; González-Tajuelo, R.; Domenech, M.; González-Camacho, F.; Sánchez-Madrid, F.; Brown, J.S.; García, E.; Yuste, J. PSGL-1 on leukocytes is a critical component of the host immune response against invasive pneumococcal disease. PLoS Pathog. 2016, 12, e1005500. [CrossRef]

30. Ramos-Sevillano, E.; Urzainqui, A.; Campuzano, S.; Moscoso, M.; González-Camacho, F.; Domenech, M.; Rodríguez de Córdoba, S.; Sánchez-Madrid, F.; Brown, J.S.; García, E.; et al. Pleiotropic effects of cell wall amidase LytA on Streptococcus pneumoniae sensitivity to the host immune response. Infect. Immun. 2015, 83, 591-603. [CrossRef]

31. Yuste, J.; Fenoll, A.; Casal, J.; Giménez, M.J.; Aguilar, L. Combined effect of specific antibodies (as serotherapy or preimmunization) and amoxicillin doses in treatment of Streptococcus pneumoniae sepsis in a mouse model. Antimicrob. Agents Chemother. 2002, 46, 4043-4044. [CrossRef]

32. Tarragó, D.; Lara, N.; Fenoll, A.; Casal, J.; Giménez, M.J.; Aguilar, L.; Sevillano, D. Specific antibodies, levofloxacin, and modulation of capsule-associated virulence in Streptococcus pneumoniae. Antimicrob. Agents Chemother. 2005, 49, 3095-3096. [CrossRef]

33. Yuste, J.; Jado, I.; Fenoll, A.; Aguilar, L.; Giménez, M.J.; Casal, J. Beta-lactam modification of the bacteraemic profile and its relationship with mortality in a pneumococcal mouse sepsis model. J. Antimicrob. Chemother. 2002, 49, 331-335. [CrossRef] [PubMed]

34. Alkorta, M.; Giménez, M.J.; Vicente, D.; Aguilar, L.; Pérez-Trallero, E. In vivo activity of gemifloxacin, moxifloxacin and levofloxacin against pneumococci with gyrA and parC point mutations in a sepsis mouse model measured with the all or nothing mortality end-point. Int. J. Antimicrob. Agents 2005, 25, 163-167. [CrossRef]

35. Casal, J.; Aguilar, L.; Jado, I.; Yuste, J.; Giménez, M.J.; Prieto, J.; Fenoll, A. Effects of specific antibodies against Streptococcus pneumoniae on pharmacodynamic parameters of beta-lactams in a mouse sepsis model. Antimicrob. Agents Chemother. 2002, 46, 1340-1344. [CrossRef]

36. Huelves, L.; Sevillano, D.; Martínez-Marín, C.; López-Casla, M.T.; Gracia, M.; Alou, L.; del Carmen Ponte, M.; Prieto, J.; Soriano, F.; Spanish Pneumococcal Infection Study, N. Correlation between in vitro and in vivo activity of levofloxacin and moxifloxacin against pneumococcal strains with different susceptibilities to fluoroquinolones. Int. J. Antimicrob. Agents 2006, 27, 294-299. [CrossRef]

37. Onyeji, C.O.; Bui, K.Q.; Owens, R.C., Jr.; Nicolau, D.P.; Quintiliani, R.; Nightingale, C.H. Comparative efficacies of levofloxacin and ciprofloxacin against Streptococcus pneumoniae in a mouse model of experimental septicaemia. Int. J. Antimicrob. Agents 1999, 12, 107-114. [CrossRef] 
38. Yuste, J.; Botto, M.; Bottoms, S.E.; Brown, J.S. Serum amyloid P aids complement-mediated immunity to Streptococcus pneumoniae. PLoS Pathog 2007, 3, 1208-1219. [CrossRef] [PubMed]

39. Alou, L.; Giménez, M.J.; Sevillano, D.; Aguilar, L.; Cafini, F.; Echeverría, O.; Pérez-Trallero, E.; Prieto, J. A pharmacodynamic approach to antimicrobial activity in serum and epithelial lining fluid against in vivo-selected Streptococcus pneumoniae mutants and association with clinical failure in pneumonia. J. Antimicrob. Chemother. 2006, 58, 349-358. [CrossRef]

40. Sevillano, D.; Aguilar, L.; Alou, L.; Giménez, M.J.; González, N.; Torrico, M.; Cafini, F.; Fenoll, A.; Coronel, P.; Prieto, J. High protein binding and cidal activity against penicillin-resistant S. pneumoniae: A cefditoren in vitro pharmacodynamic simulation. PLoS ONE 2008, 3, e2717. [CrossRef] [PubMed]

41. Rodríguez-Avial, I.; Ramos, B.; Ríos, E.; Cercenado, E.; Ordobás, M.; Sanz, J.C.; Madrid Streptococcus pneumoniae Microbiological, Group. Clonal spread of levofloxacin-resistant Streptococcus pneumoniae invasive isolates in Madrid, Spain, 2007 to 2009. Antimicrob. Agents Chemother. 2011, 55, 2469-2471. [CrossRef]

42. Sanz, J.C.; Cercenado, E.; Marín, M.; Ramos, B.; Ardanuy, C.; Rodríguez-Avial, I.; Bouza, E. Multidrug-resistant pneumococci (serotype 8) causing invasive disease in HIV+ patients. Clin. Microbiol. Infect. 2011, 17, 1094-1098. [CrossRef] [PubMed]

43. Amin-Chowdhury, Z.; Collins, S.; Sheppard, C.; Litt, D.; Fry, N.K.; Andrews, N.; Ladhani, S.N. Characteristics of invasive pneumococcal disease caused by emerging serotypes after the introduction of the 13-valent pneumococcal conjugate vaccine in England: A prospective observational cohort study, 2014-2018. Clin. Infect. Dis. 2020, 71, e235-e243. [CrossRef]

44. Shoji, H.; Vázquez-Sánchez, D.A.; González-Díaz, A.; Cubero, M.; Tubau, F.; Santos, S.; García-Somoza, D.; Linares, J.; Yuste, J.; Martí, S.; et al. Overview of pneumococcal serotypes and genotypes causing diseases in patients with chronic obstructive pulmonary disease in a Spanish hospital between 2013 and 2016. Infect. Drug Resist. 2018, 11, 1387-1400. [CrossRef] [PubMed]

45. Craig, W.; Andes, D.A. Correlation of the magnitude of the AUC24/MIC for 6 fluoroquinolones against Streptococcus pneumoniae with survival and bactericidal activity in an animal model [abstract 289]. In Proceedings of the Program and abstracts of the 40th Interscience Conference of Antimicrobial Chemotherapy (Toronto), Toronto, ON, Canada, 17-20 September 2000; American Society for Microbiology: Washington, DC, USA, 2000; Volume 7.

46. Ambrose, P.G.; Bhavnani, S.M.; Rubino, C.M.; Louie, A.; Gumbo, T.; Forrest, A.; Drusano, G.L. Pharmacokineticspharmacodynamics of antimicrobial therapy: It's not just for mice anymore. Clin. Infect. Dis. 2007, 44, 79-86. [CrossRef] [PubMed]

47. Bowker, K.E.; Garvey, M.I.; Noel, A.R.; Tomaselli, S.G.; Macgowan, A.P. Comparative antibacterial effects of moxifloxacin and levofloxacin on Streptococcus pneumoniae strains with defined mechanisms of resistance: Impact of bacterial inoculum. J. Antimicrob. Chemother. 2013, 68, 1130-1138. [CrossRef]

48. Hoet, S.; Stevigny, C.; Block, S.; Opperdoes, F.; Colson, P.; Baldeyrou, B.; Lansiaux, A.; Bailly, C.; Quetin-Leclercq, J. Alkaloids from Cassytha filiformis and related aporphines: Antitrypanosomal activity, cytotoxicity, and interaction with DNA and topoisomerases. Planta Med. 2004, 70, 407-413. [CrossRef]

49. Sobarzo-Sánchez, E.; Soto, P.G.; Valdés Rivera, C.; Sánchez, G.; Hidalgo, M.E. Applied biological and physicochemical activity of isoquinoline alkaloids: Oxoisoaporphine and boldine. Molecules 2012, 17, 10958-10970. [CrossRef]

50. Ferrándiz, M.J.; Hernández, P.; de la Campa, A.G. Genome-wide proximity between RNA polymerase and DNA topoisomerase I supports transcription in Streptococcus pneumoniae. PLoS Genet. 2021, 17, e1009542. [CrossRef] 